\title{
2 \\ From Samoa to CAEPR via Mumeka: The hybrid economy comes of age
}

\section{Geoff Buchanan}

\section{Introduction}

In 2001, Jon Altman introduced the hybrid economy framework as a means of addressing the economic development problem faced by Indigenous people living on Aboriginal land in remote and regional Australia. For Altman, the distinctive economies in these locationsmade up of market, state and customary components - were poorly understood 'by politicians, policy makers and Indigenous people and their representative organisations alike' (2001: v). The hybrid economy framework was subsequently depicted as a Venn diagram emphasising the linkages and interdependencies of the three overlapping sectors (see Fig. 2.1).

Altman argued that to understand the hybrid economy required 'a hybrid analytical framework that combines science, social sciences and Indigenous knowledge systems' (2001: v). The framework was developed at a time when, as a social scientist, Altman was collaborating with biological scientists at the Key Centre for Tropical Wildlife Management and with Bawinanga Aboriginal Corporation in Maningrida, central Arnhem Land. Emphasis was placed on the role 
such a framework might play in achieving 'sustainable development on Aboriginal land in the twenty-first century' (Altman 2001: v), particularly through the customary and commercial use of wild resources. For Altman, the fundamental development dilemma was how to grow the hybrid economy-primarily through the expansion of the customary and market sectors - given that state intervention was thought to have peaked.

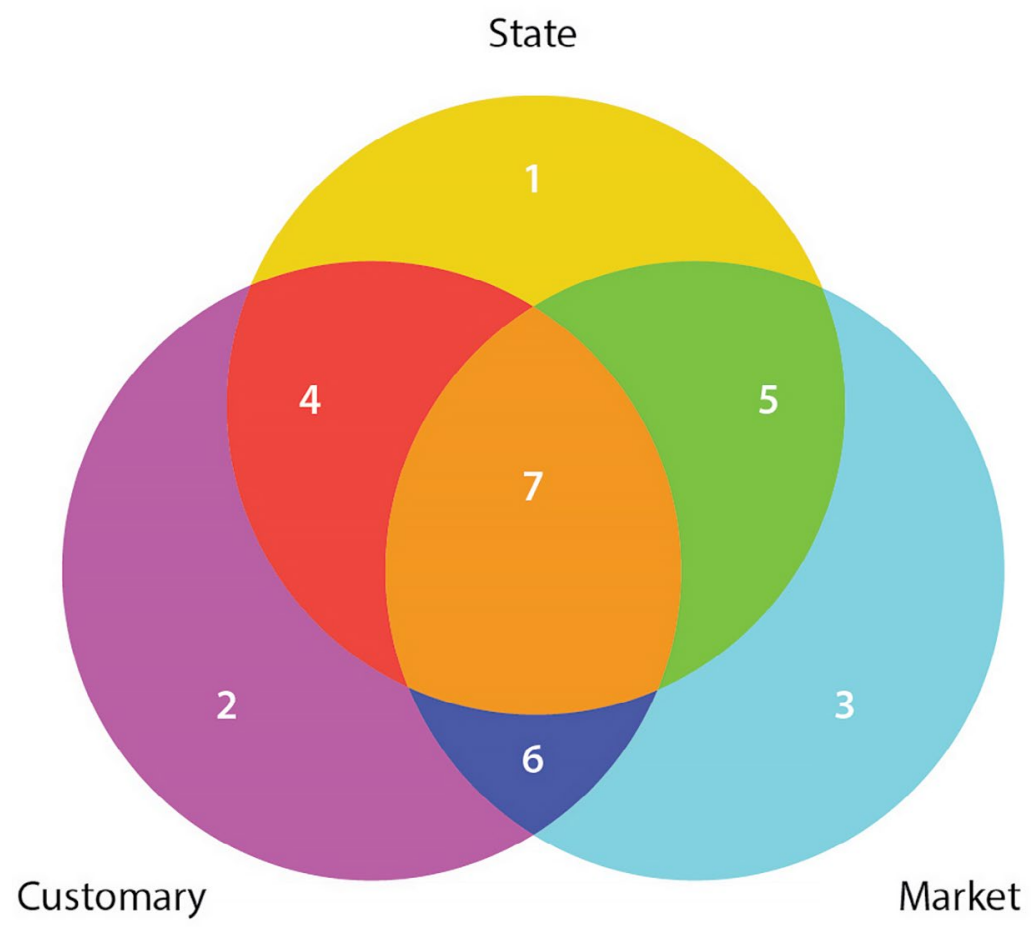

Fig. 2.1 The hybrid economy model

Source: Altman (2005)

In this chapter, I provide a truncated genealogy of the hybrid economy. I dig among Altman's earliest research to expose some of the roots of the hybrid economy. One of these roots can be traced back to Samoa. Another can be traced along a circuitous route from remote Australia to rural China and back. These roots reveal that hybridity has long been at the heart of Altman's engagement with Indigenous economyan engagement that has sought to illuminate and appreciate economic difference via an anthropological consciousness. 


\section{A brief genealogy of the hybrid economy}

A detailed genealogy of the hybrid economy might start with linguistic roots. According to the Oxford English Dictionary, the word 'hybrid' has its roots in the realm of animal husbandry, deriving from the Latin hybrida: the offspring of a tame sow and wild boar. The ancient Greek roots of 'economy' also relate to husbandry, but in the sense of 'the administration and management of a household; domestic economy'. This etymology provides rich ground for a lengthy discussion, but lacking that luxury, the starting point of this genealogy is neither Greece nor Rome, but the islands of Samoa. Samoa is a place with which Jon and I share a connection. For both of us it represents a site of our early engagement with Indigenous economy. Western Samoa, as it was then called, was a key case study site for Altman's MA (Hons) in Economics undertaken at the University of Auckland between 1974 and 1976. Altman's Master's thesis examined export instability and economic growth in Pacific Island economies, including Samoa. I had lived in Samoa in 2003 and worked as a volunteer with an environmental nongovernment organisation there. This perhaps stood me in good stead when I applied for a position as Altman's research assistant at the Centre for Aboriginal Economic Policy Research (CAEPR) in 2004. I recall a tropical Samoan vibe at my job interview where Professor Altman was dressed in his formal summer attire of t-shirt, shorts and sandals.

\section{Subsistence affluence and Fred Fisk's influence: Opportunity and response}

Samoa saw Altman's formal engagement with development dilemmas in an Indigenous economy characterised by both a subsistence and market sector. In an article published in 1978, he stated that the Samoan economy was in a state of transition from being a predominantly primitive subsistence-based economy to a market economy' (1978: 39). At the same time, he noted that subsistence affluence remained a real alternative for Samoan agricultural producers and acted as a disincentive to engage with a market economy characterised by export instability. Altman's view here was influenced by Fred Fisk's model of development based on the rural sector of Papua New Guinea. 
Fisk's theoretical influence related to his contributions to the 'opportunity and response' school of thought. At the core of opportunity and response theory was the view 'that contact between capitalist and non-capitalist economic systems results in the former providing opportunities to which the latter respond in varying degrees' (Altman 1987: 7). Under Fisk's own model, contact with capitalism saw the virtual disappearance of the pure subsistence unit while groups' engagement in cash production was based on their response to the force of incentives. For Fisk, this 'response factor' was 'determined by internal factors: the cultural, economic and political characteristics of the group modified by external factors' (Altman 1978: 39). Moving his focus from Samoa to Australia, Altman's early research on outstation economies reveals Fisk's ongoing influence.

In 1977 Altman took part in a study at the Economics Department at the University of Melbourne exploring the economic status of Australian Aborigines. The study resulted in a landmark book co-authored by Altman and John Nieuwenhuysen (1979). The book's authors drew on Fisk's work to produce a formal economic model of outstation economies based on three scenarios: pre-contact, contemporary, and prospective (Altman \& Nieuwenhuysen 1979: 208-10) (see Fig. 2.2). This modelling suggested that contemporary-or 'neo-traditional'hunting and gathering, aided by Western technology and production techniques and access to the market for basic needs, resulted in a drop in demand for subsistence goods and a labour surplus available for cash income earning activities. While the contemporary scenario suggested a form of subsistence affluence, the prospective model raised concerns about sustainability in a context of permanent settlements, population growth and resource depletion. 
Fig. 2.2 Decentralised communities: A model

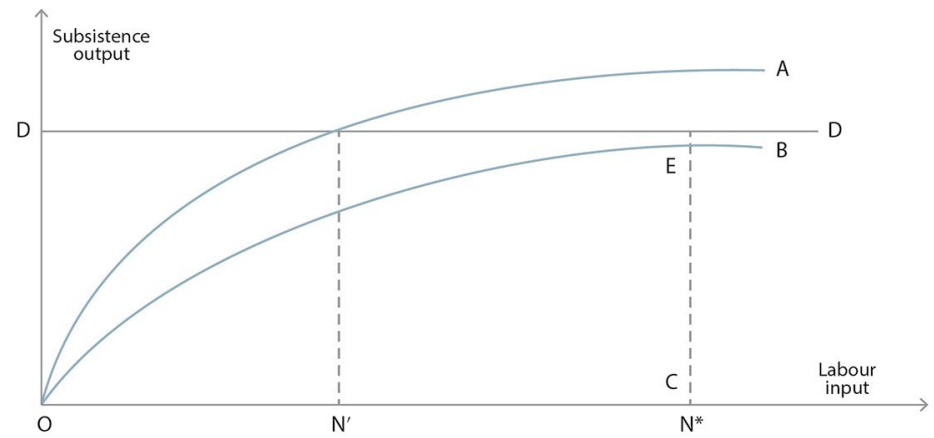

2.2.1 Traditional (pre-contact) household production scenario

Source: Altman \& Nieuwenhuysen (1979: 208-10)

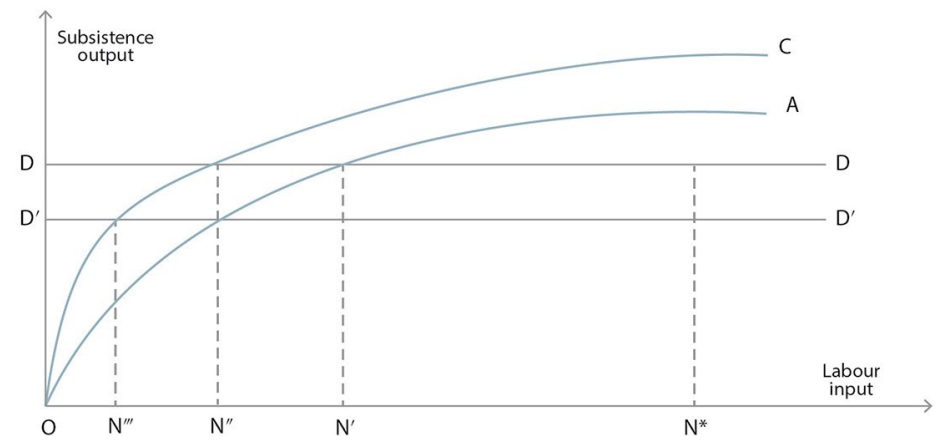

2.2.2 Neo-traditional (post-contact) household production scenario Source: Altman \& Nieuwenhuysen (1979: 208-10)

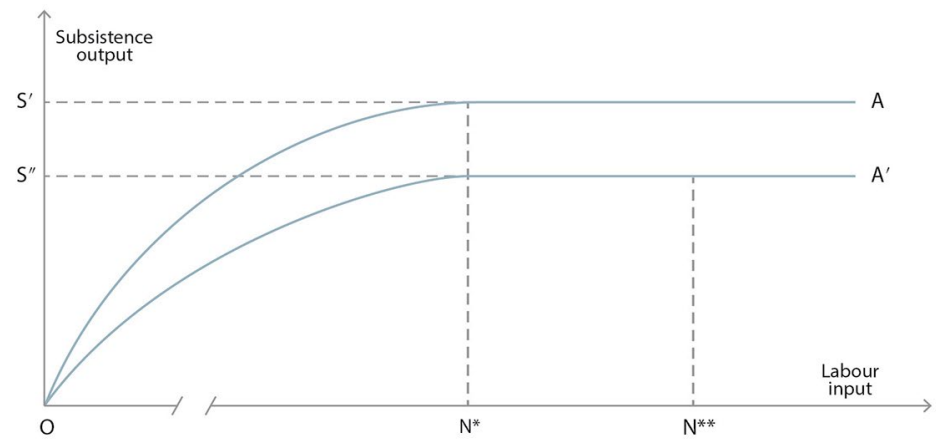

2.2.3 Prospective household production scenario

Source: Altman \& Nieuwenhuysen (1979: 208-10) 
Altman and Nieuwenhuysen described decentralised community economies not as a hybrid, but as 'an amalgam of traditional and marketoriented economic activities' (1979: 96). It was while working on this study that Altman realised, as an economist, the 'need to transcend the disciplinary boundaries between economics and anthropology' (Altman 1987: xii). In these early publications we see the emergence of two fundamental elements of Altman's hybrid economy. First is his focus on the subsistence or customary sector and its relationship with the capitalist economy. Second is his emphasis on the need for an interdisciplinary analytical and intellectual framework. My focus in this chapter is on the first element, though in a sense it cannot be separated from the second.

In 1978 Altman transitioned from Melbourne to Canberra, from economics to anthropology, and from macro-level to micro-level analysis. As a doctoral candidate at the Department of Prehistory and Anthropology at The Australian National University, Altman undertook ethnographic fieldwork in 1979-80. He participated in and observed in great detail the outstation economy of Kuninjku people at Mumeka in the Maningrida region of central Arnhem Land. Fisk's influence is acknowledged in Altman's adaptation of the formal economic tool of social accounting to attribute an imputed income value to subsistence production alongside cash income from art and craft production and social security payments (Altman 1982, 1987). Fisk was one of Altman's examiners and he subsequently drew on Altman's research to estimate the contribution of the customary sector to outstation economies as part of his survey of the contemporary Aboriginal economy in town and country (see Fisk 1985).

In Altman's view, the failure of formal economics to measure nonmonetary productive activities was due to their being seen as 'antithetical to the capitalist or market ideology' (Altman 1987: 47). This view persists in his work and underpins the hybrid economy as a challenge to neoliberal normalisation under late capitalism. Altman has long argued for the formal measurement of the subsistence, informal or customary sector and the recognition of the sector's significance by policy makers. His persistence has at the very least resulted in the inclusion of questions around people's participation in the customary sector in the Australian Bureau of Statistics' National Aboriginal and Torres Strait Islander Social Survey-though not yet to Altman's satisfaction (Altman \& Allen 1992; Altman et al. 2006, 2012). 


\section{A circuitous root: Articulation theory and economic hybridity}

Altman's PhD thesis critically engaged with the development and underdevelopment paradigms as a means of explaining the economic changes experienced by the Kuninjku residents of Mumeka (Altman 1982, 1987). Fisk's opportunity and response school of thought fits within the development paradigm. From the underdevelopment paradigm Altman drew on the Marxist framework known as 'articulation of modes of production' or 'articulation theory' (Altman 1987: 8-9). For Altman, a key limitation of both paradigms was their failure to recognise people's agency or autonomy in the face of capitalism. His approach sought to combine elements of both paradigms to examine 'the possibilities that the positive benefits of capitalism may be utilised, or that indigenous minorities may regard themselves as exploiters of the capitalist system' (Altman 1987: 9).

Altman's conclusion emphasised the resilience of the customary economy and the relative autonomy of Kuninjku people:

[The Mumeka economy] has demonstrated remarkable resilience in adapting to changed circumstances after colonisation. ... Eastern Gunwinggu [Kuninjku] people have adapted their economy to incorporate some elements of the alien system, while maintaining many of their own cultural and economic practices. Rather than just responding to changed circumstances these people have continued to create their own social and economic environment within the new structural limitations placed on their lifestyle by the wider Australian society. With this autonomy, eastern Gunwinggu people have chosen to maintain their hunter-gatherer economy in modern Australia (1987: 236).

This conclusion is echoed in Frances and Howard Morphy's recent observation that Yolngu engagement with the three sectors of Altman's hybrid economy 'comes from a relatively autonomous position''enabling them to create an economy in place that articulates with the overall sociocultural trajectory of their society' (Morphy \& Morphy 2013: 180). Morphy and Morphy caution that, by being nested in the notion of 'the intercultural', the hybrid economy concept may draw attention away from people's agency and effectively separate the economic from the sociocultural context. They put forward the notion of relative autonomy-adapted from structural Marxism-as an 
important corrective to theories of the intercultural and hybridity. Looking back we see that as a doctoral student whose supervisory panel included Howard Morphy, Altman saw relative autonomy as an important corrective to structural Marxism in the form of articulation theory, emphasising Kuninjku people's choice to live a 'relatively autonomous lifestyle' at Mumeka (1982: 32). In Altman's own words, 'things go round' (JC Altman, pers. comm., 1 November 2014).

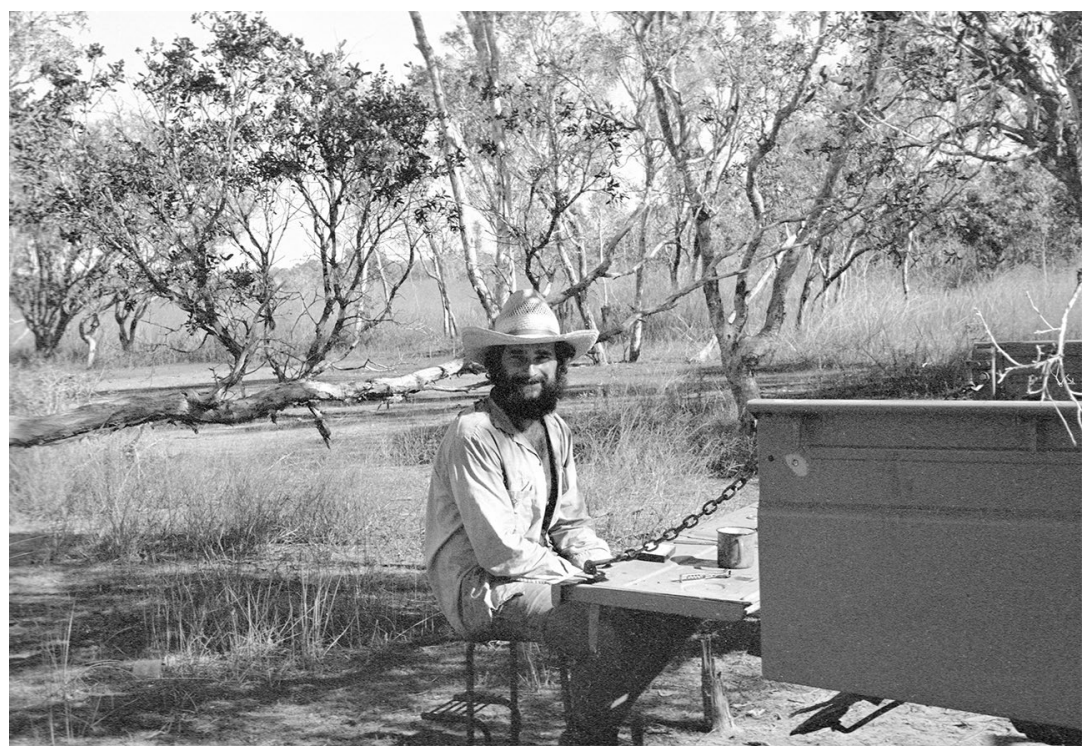

Fig. 2.3 Jon Altman at work, Gurror outstation, Maningrida region, north-central Arnhem Land, Northern Territory, May 1980 Photo: Jon Altman Collection, courtesy of AIATSIS

A similar corrective to articulation theory lies at the heart of the notion of economic hybridity from which the hybrid economy got its name. Altman (2009) cites a paper by Mayfair Yang on economic hybridity in Wenzhou in rural China as the inspiration for the term 'the hybrid economy'. In that paper, Yang (2000) puts forward the notion of 'economic hybridity' as an alternative to articulation theory. For Yang, 'the integration and fusion within organic structure which is encapsulated in the notion of hybridity' recommended itself over articulation theory 'wherein modes are presented as more or less intact, distinct, and separate' (Yang 2000: 478). Yang's paper was inspired by Gibson-Graham's 'call for a theoretical move away from a model of monolithic global capitalism and notions of one-way 
"penetration" of capitalism' (Yang 2000: 477). As had Altman before them, Yang (2000) and Gibson-Graham (2006) acknowledged the positive role articulation theory played in capturing the heterogeneity of economies while rejecting its view 'that capitalism has inevitable penetrative powers' and that 'pre-capitalist relations of production are always transformed on contact with capitalism' (Altman 1987: 225).

For Yang, the logic of economic hybridity is subversive of capitalist principles - contesting and rechannelling capitalism toward alternative ends. Yang draws on Baudrillard's critique of historical materialism and the failure of Marxism 'to achieve a radical break from capitalist epistemology' (Yang 2000: 482). For Baudrillard, this included a failure to recognise the articulation between economics and other social relations in pre-capitalist societies - ultimately doing violence to these societies where 'the point of life and structural order are predicated not on production but on symbolic exchange with humans, spirits, and ancestors' (Yang 2000: 482). In line with the notion of relative autonomy, economic hybridity is based on the view that local sociocultural structures and mechanisms inform economic practice. For Yang it is these structures that 'ensure local autonomy from external forces such as the centralized state and capitalism' (2000: 493). And so, in Yang's discussion of economic hybridity in rural Wenzhou's ritual economy we hear echoes of Altman's discussion of relative autonomy in remote Mumeka's hybrid economy.

\section{Conclusion: Illuminating Indigenous economy through hybridity}

In his earliest engagements with Indigenous economy in Samoa and Australia, Altman applied formal economic techniques to analyse the informal economy following Fred Fisk's example. In the production of social accounts of state, market and customary contributions to the Mumeka economy we clearly see the methodological and empirical foundations of the hybrid economy in Altman's doctoral research. We also find the notion of relative autonomy being used as a critical corrective to the Marxist framework of articulation of modes of production. In turn, we find a clear theoretical link with the notion of economic hybridity as an alternative to articulation theory. 
Yang's notion of economic hybridity was derived from Mikhail Bakhtin's notion of linguistic hybridity. Bakhtin's notion refers to the ability of language to be double-voiced. As Young puts it: 'Hybridity is itself an example of hybridity, of a doubleness that both brings together, fuses, but also maintains separation' (1995: 22). Bakhtin made a distinction between unconscious, organic hybridisation and conscious, intentional hybridity: while organic hybridity gives birth to an amalgamation, intentional hybridity creates division and separation through contestation (Young 1995). We might then read Altman's writing on the hybrid economy as a form of linguistic hybridity wherein there is an amalgamation that stresses separation. In these terms, the hybrid economy gives birth to an economic amalgamation in order to argue for an alternate development trajectory on the Indigenous estate.

To borrow from Bakhtin, the hybrid economy can be seen as a mixture of two social science languages within the limits of a single concept, an encounter of two different disciplinary consciousnessesanthropological and economic - separated from one another by disciplinary boundaries (see Bakhtin 1981: 358). We might also describe Altman's hybrid analytical framework as an epistemic hybrid: an organised system for bringing different knowledges in contact with one another; a system having as its goal the illumination of Indigenous economies by means of various knowledges, and the carving out of livelihoods through alternate development (see Bakhtin 1981: 361).

Evidently, hybridity has long been at the heart of Jon Altman's engagement with Indigenous economy. The hybrid economy is the result (and continuation) of a long-term anthropological engagement with development dilemmas in Indigenous Australia and with policy discourse in Indigenous affairs. Throughout this engagement Altman has untiringly argued for alternate development based on an appreciation of economic difference. He has transcended disciplinary boundaries, combined paradigms, synthesised theories, established and led a multidisciplinary research centre, and brought together social sciences, biophysical sciences and Indigenous knowledge systems to explore hybrid economic futures on the Indigenous estate. Hybrid research has been part and parcel of Altman's engagement and has been fundamental to the development of the hybrid economy (Altman 2001, Altman \& Cochrane 2005, Altman \& Kerins 2012). 
Digging among the roots of the hybrid economy reveals continuity amidst change in a career dedicated to illuminating Indigenous economy by embracing hybridity.

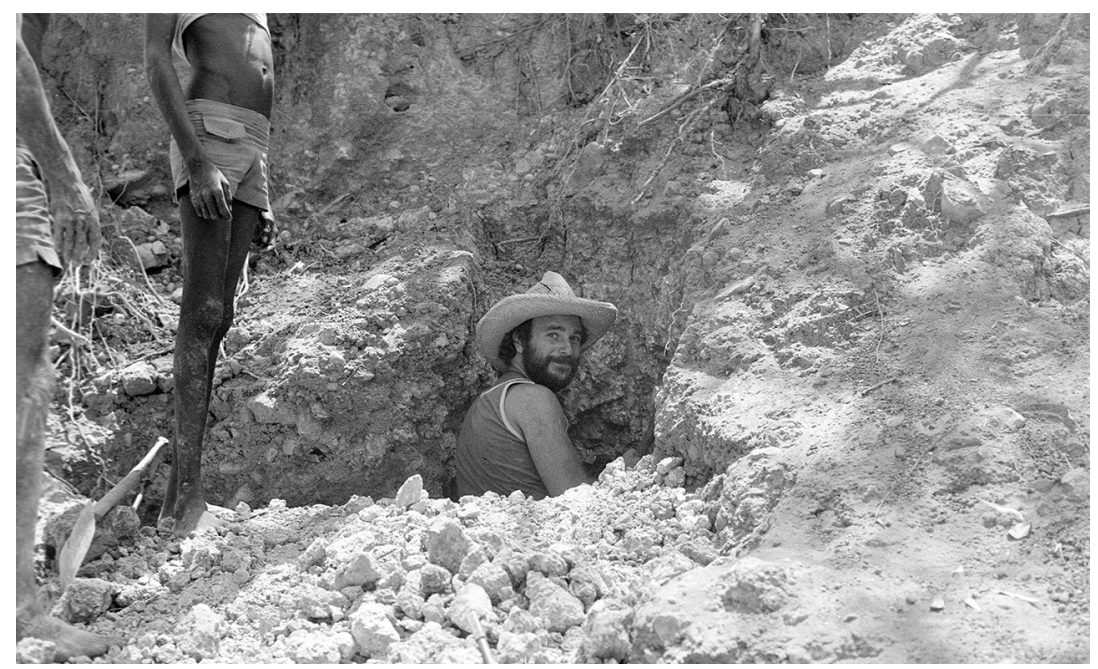

Fig. 2.4 Jon Altman digging for white pigment at Gudjangal, Maningrida region, north-central Arnhem Land, Northern Territory, September 1980

Photo: Jon Altman Collection, courtesy of AIATSIS

\section{References}

Altman JC (1978). Export instability and its consequences for economic growth and development: Western Samoa. Pacific Viewpoint 19(1):26-46.

Altman JC (1982). Hunter-gatherers and the state: the economic anthropology of the Gunwinggu of north Australia, PhD thesis, The Australian National University, Canberra.

Altman JC (1987). Hunter-gatherers today: an Aboriginal economy in north Australia, Australian Institute of Aboriginal Studies, Canberra. 
Altman JC (2001). Sustainable development options on Aboriginal land: the hybrid economy in the 21st century, Discussion Paper 226, Centre for Aboriginal Economic Policy Research, The Australian National University, Canberra.

Altman JC (2005). Economic futures on Aboriginal land in remote and very remote Australia: hybrid economies and joint ventures. In Austin-Broos D \& Macdonald G (eds), Culture, economy and governance in Aboriginal Australia, University of Sydney Press, Sydney.

Altman JC (2009). The hybrid economy and anthropological engagements with policy discourse: a brief reflection. The Australian Journal of Anthropology 20(3):318-29.

Altman JC \& Allen LM (1992). Aboriginal and Torres Strait Islander participation in the informal economy: statistical and policy implications. In Altman JC (ed.), A national survey of Indigenous Australians: options and implications, CAEPR Research Monograph No. 3, Centre for Aboriginal Economic Policy Research, The Australian National University, Canberra.

Altman JC, Biddle N \& Buchanan G (2012). The Indigenous hybrid economy: can the NATSISS adequately recognise difference? In Hunter B \& Biddle N (eds), Survey analysis for Indigenous policy in Australia: social science perspectives, CAEPR Research Monograph No. 32, ANU E Press, Canberra.

Altman JC, Buchanan G \& Biddle N (2006). Measuring the 'real' Indigenous economy in remote Australia using NATSISS 2002. Australian Journal of Labour Economics 9(1):17-31.

Altman JC \& Cochrane M (2005). Sustainable development in the indigenous-owned savanna: innovative institutional design for cooperative wildlife management. Wildlife Research 32:473-80.

Altman JC \& Kerins S (eds) (2012). People on country: vital landscapes, Indigenous futures, The Federation Press, Sydney.

Altman JC \& Nieuwenhuysen JP (1979). The economic status of Australian Aborigines, Cambridge University Press, Cambridge. 
Bakhtin MM (1981). The dialogic imagination, University of Texas Press, Austin.

Fisk EK (1985). The Aboriginal economy in town and country, George Allen \& Unwin, Sydney \& Australian Institute of Aboriginal Studies, Canberra.

Gibson-Graham JK (2006). The end of capitalism (as we know it): a feminist critique of political economy, 2nd edn, University of Minnesota Press, Minneapolis.

Morphy F \& Morphy H(2013). Anthropological theory and government policy in Australia's Northern Territory: the hegemony of the 'mainstream'. American Anthropologist 115(2):174-87.

Oxford English Dictionary (OED) Online (2014). Oxford University Press, Oxford.

Yang MM (2000). Putting global capitalism in its place: economic hybridity, Bataille, and ritual expenditure. Current Anthropology, 41(4):477-509.

Young RJC (1995). Colonial desire: hybridity in theory, culture, and race, Routledge, London. 
This text is taken from Engaging Indigenous Economy: Debating diverse approaches, edited by Will Sanders, published 2016 by ANU Press, The Australian National University, Canberra, Australia. 